\title{
Peran Profesionalisme Tutor Dalam Meningkatan Motivasi Belara Pada Warga Belajar Paket C Di PKBM Al-Muttaqin Desa Banjarsengon Kecamatan Patrang Kabupaten Jember
}

\author{
Domas Adi Saputro, A.T. Hendra Wijaya, Lutfi Ariefianto \\ Pendidikan Luar Sekolah, Universitas Jember. Jl. Kalimantan No. 37, Tegal Boto, Jember 62811, \\ Indonesia \\ Email: domasadi26@gmail.com, hendrawijayapls.fkip@unej.ac.id, lutfipls.fkip@unej.ac.id
}

\begin{abstract}
Abstrak
Program paket C setara dengan SMA/MA berfungsi untuk menuntaskan wajib belajar 9 tahun. Salah satu lembaga yang menyelenggarakan program paket $\mathrm{C}$ adalah Pusat Kegiatan Belajar Masyarakat (PKBM) Al-Muttaqin Desa Banjarsengon Kecamatan Patrang Kabupaten Jember. Dalam pelaksanaan pembelajaran di PKBM ini harus ada seorang pendidik atau disebut dengan tutor yang profesional sehingga mampu meningkatkan kualitas pendidikan. Metode penelitian yang digunakan yaitu jenis penelitian deskriptif dengan pendekatan kualitatif. Hasil penelitian ini menemukan bahwa pendidikan kesetaraan program paket C, Tutor sudah mampu memenuhi standar kompetensi dalam merencanakan pembelajaran, dilihat dari mempersiapkan silabus, membuat RPP, kompetensi dasar, dan lainnya. Pembelajaran yang dilakukan juga telah sesuai dengan kurikulum yang ada. Motivasi belajar terhadap warga belajar dalam mengikuti pembelajaran mandiri terdiri dari motivasi instrinsik dan motivasi ekstrinsik Motivasi belajar pada warga belajar sudah memiliki motivasi yang baik dalam melaksanakan belajar mandiri. Peran tutor disini sebagai informator, organisator, pembimibing, inisiator, motivator, mediator, fasilitator,dan evaluator.
\end{abstract}

Kata Kunci : Peran Tutor, Profesionlisme, Motivasi Belajar.

\section{The Role Of Tutor Professionalism In Improving Learning Motivation In Citizens Learning Package C On PKBM Al-Muttaqin Banjarsengon, Patrang, Jember}

\begin{abstract}
The package C program is equivalent to a senior high school / MA function to complete 9year compulsory education. One of the institutions that organizes the package $C$ program is the Community Learning Center (CLC) which takes place at CLC Al-Muttaqin, Banjarsengon Village, Patrang District, Jember Regency. In the implementation of learning in CLC there must be an educator or called a professional tutor so as to improve the quality of education. The research method used is a type of descriptive research with a qualitative approach. The results of this study found that the education of equality in the package $C$ program, Tutor was able to meet competency standards in planning learning, seen from preparing syllabus, making lesson plans, basic competencies, and others. The learning done is also in accordance with the existing curriculum. Motivation to learn towards the learning population in participating in independent learning consists of intrinsic motivation and extrinsic motivation. Learning motivation in the learning community already has good motivation in carrying out independent learning. The role of the tutor is here as an informator, organizer, supervisor, initiator, motivator, mediator, facilitator, and evaluator.
\end{abstract}

Keywords: Role of Tutors, Professionalism, Learning Motivation. 


\section{Learning Community: Jurnal Pendidikan Luar Sekolah, 3 (2), September 2019 - 71}

Domas Adi Saputro

\section{PENDAHULUAN}

Pusat Kegiatan Belajar Masyarakat (PKBM) adalah salah satu program Pendidikan Non Formal Kesetaraan Paket C yang bertujuan untuk memberikan layanan Pendidikan Non Formal sebagai penambah, pengganti dan pelengkap pendidikan formal bagi masyarakat yang membutuhkan pengetahuan, ketrampilan, kecakapan hidup, dan kepribadian agar bisa mengekspresikan dirinya dalam proses belajar.

Dalam pelaksanaan pembelajaran di PKBM, seorang tutor berperan penting dalam mewujudkan tujuan pembelajaran dan memberikan materi pembelajaran. Dikutip dari Moelong (2005). Dengan tujuan mewujudkan pembelajaran dan memberi materi pembelajaran kepada warga belajar, seorang tutor harus memiliki kompetensi, kompetensi disini adalah kemampuan dasar yang dimilki oleh seseorang yang berkaitan dengan lingkungan pekerjaan, baik sebagai individu maupun bekerja. Sedangkan menurut "Holmes (1992) kompetensi adalah kemampuan yang harus ditunjukkan di lingkungan kerja dalam bentuk perilaku dan hasil kerja". Tetapi, kenyataan di lapangan, pelaksanaan pembelajaran banyak yang tidak disesuaikan dengan standar yang sudah ada. Dari permasalahan diatas, menunjukkan bahwa standar proses pembelajaran pada tutor seharusnya diselenggarakan secara interaktif, inspiratif, menyenangkan, menantang, memotivasi warga belajar untuk berpartisipasi aktif dalam memotivasi warga belajar untuk mandiri serta memberikan ruang yang cukup bagi prakarsa, kreativitas dan kemandirian sesuai bakat, minat dan perkembangan fisik serta psikologis warga belajar.

Oleh karena itu upaya perbaikan apapun yang dilakukan untuk meningkatkan kualitas pendidikan harus didukung oleh tutor yang profesional dan berkualitas. Profesional berasal dari kata profesi artinya satu bidang pekejaan yang ingin atau akan ditekuni oleh seseorangs belajar. Rumusan penelitian ini adalah Bagaimana Peran Profesionalisme Tutor dalam meningkatkan Motivasi Belajar pada warga belajar paket $\mathrm{C}$ di PKBM Al-Muttaqin Desa Banjarsengon Kecamatan Patrang kabupaten Jember.

\section{METODE}

Penelitian ini merupakan penelitian deskriptif dengan pendekatan kualitatif. Subjek penelitian ini terdiri dari 2 (dua) informan kemudian terbagi menjadi informan kunci dan informan pendukung. Tempat lokasi penelitian ini yaitu di PKBM Al-Muttaqin Desa Banjarsengon Kecamatan Patrang Kabupaten Jember. Metode pengumpulan data yang digunakan terdiri dari metode: wawancara, observasi dan dokumentasi. Teknik keabsahan data yakni perpanjangan pengamatan penelitian, meningkatkan ketekunan dan triangulasi menggunakan triangulasi sumber dan teknik. Analisis data dilakukan dengan menggunakan analisis model Miles dan Huberman yakni pengumpulan data, reduksi data, pemaparan data dan penarikan kesimpulan.

\section{HASIL DAN PEMBAHASAN}

Berdasarkan hasil penelitian peran profesionalisme tutor dalam meningkatkan motivasi belajar pada warga belajar paket $C$ di PKBM Al-Muttaqin Desa Banjarsengon Kecamatan Patrang Kabupaten Jember sebagai berikut:

Tutor sudah memenuhi standar kompetensi dalam merencanakan pembelajaran, dilihat dari mempersiapkan silabus, membuat RPP, Kompetensi dasar, dan lainnya. Pembelajaran yang dilakukan juga telah sesuai dengan kurikulum yang ada. Sedangkan dengan pelaksanaan pembelajaran tutor juga berpacu dengan apa yang telah disusun melalui RPP, begitupun pembelajaran yang dilakukan di dalam kelas atau materi-materi yang telah disusun sesuai dengan kurikulum yang ada. Pelaksanaan di dalam kelas juga berjalan dengan baik, tutor sangat menguasai dengan materi yang akan diajarkan terhadap warga belajar. Begitu juga dengan hal tutor dalam menilai hasil belajar warga belajar juga telah dengan tuntutan standar penilaian yang berlaku, dengan melakukan tes dan remidi untuk menentukan hasil dari pencapaian warga belajar selama belajar di PKBM Al-Muttaqin Desa Banjarsengon Kecamatan Patrang Kabupaten Jember. Hal ini sejalan dengan pemikiran Hunt dalam (Majid, 2005:94) bahwa unsur- 
unsur perencanaan pembelajaran tersebut adalah mengidentifikasi kebutuhan warga belajar, tujuan yang hendak dicapai, berbagai strategi dan skenario yang relevan digunakan untuk mencapai tujuan, dan kriteria evaluasi. Sebagaimana menurut Sudjana (2009:10) hasil belajar adalah kemampuan yang dimiliki siswa setelah menerima pengalaman saat mengikuti pembelajaran. Dalam Peraturan Menteri Pendidikan Nasional No 3 Tahun 2008 tentang Standar proses pendidikan kesetaraan program Paket A, program Paket B dan Program Paket C, penilaian dilakukan oleh pendidik terhadap hasil pembelajaran untuk mengukur tingkat pencapaian warga belajar, serta digunakan sebagai bahan penyusunan laporan kemajuan hasil belajar, dan memperbaiki proses pembelajaran.

Kegiatan pembelajaran mandiri dilakukan setelah kegiatan pembelajaran tatap muka dan tutorial dirancang dalam bentuk pemberian tugas melalui modul. Warga belajar disini diberikan kebebasan dalam memilih media belajar. Kemudian pengelolaan pembelajaran mandiri meliputi perencanaan, pelaksanaan dan evaluasi sejauh ini sudah baik dalam mengelola akan tetapi perlu adanya optimalisasi pengelolaan pembelajaran. Motivasi belajar terhadap warga belajar dalam mengikuti pembelajaran mandiri terdiri dari motivasi instrinsik dan motivasi ekstrinsik, motivasi belajar secara keseluruhan peserta didik memiliki motivasi yang kurang baik dalam melaksanakan belajar mandiri, sehingga perlu adanya peningkatan motivasi dari dalam maupun luar dirinya. Dalam kegiatan belajar mandiri peran tutor tetap diperlukan dalam rangka membantu permasalahan belajar terhadap warga belajar. Adapun langkah kegiatan belajar mandiri yaitu 1) Pemberian motivasi, dimana tutor memberikan dorongan dan rangsangan positif yang mengarahkan pada kegiatan belajar mandiri; 2) menyepakati waktu penyelesaian tugas dengan warga belajar; 3) warga belajar mengerjakan tugas yang telah diberikan kemudian mengumpulkan tugas tersebut diwaktu yang telah disepakati sebelumnya; 4) membahas serta menilai hasil tugas tersebut. Peran yang dimiliki oleh tutor yaitu peran sebagai motivator yaitu tutor memotivasi yang menyangkut belajar terhadap warga kelompok dalam memberikan dorongan dengan cara memberikan penilaian, pujian, nasihat. Oleh karena itu, tutor yang berkompeten harus memiliki : a) Pemahaman terhadap karakteristik warga belajarnya, b) Penguasaan bidang studi, baik dari sisi keilmuan maupun kependidikan, c) Kemampuan penyelenggaraan pembelajaran yang mendidik, d) Kemauan dan kemampuan dalam mengembangkan profesionalitas dan kepribadian secara berkelanjutan. Jadi motivasi belajar disini dibedakan menjadi 2 jenis, dalam hal ini menurut Djamarah (2002), motivasi terbagi menjadi 2 jenis yaitu motivasi instrinsik dan motivasi ekstrinsik.

\section{SIMPULAN}

Berdasarkan hasil penelitian dan pembahahasan dapat disimpulkan sebagai berikut: (1) Tutor sudah menjalankan peran profesionalisme di PKBM Al-Muttaqin sangat baik. (2) Motivasi belajar terhadap warga belajar dalam mengikuti pembelajaran mandiri terdiri dari motivasi instrinsik dan motivasi ekstrinsik, motivasi belajar secara keseluruhan warga belajar memiliki motivasi yang baik dalam melaksanakan belajar mandiri. Sedangkan faktor pendorongnya yaitu ketersediaannya tempat belajar, antusias warga untuk belajar serta kesadaran tutor untuk mengajar.

\section{DAFTAR PUSTAKA}

Arikunto, S. 2010. Prosedur Penelitian Suatu Pendekatan Praktik. Jakarta: Rineka Cipta.

Depdiknas. 2007. Acuan Pembelajaran Pendidikan Kesetaraan Program Paket ABC. Direktorat Jenderal Pendidikan Luar Sekolah dan Pemuda. Jakarta: Depdiknas.

Masundawa, Y. 2013. Pengaruh Motivasi Intrinsik Dan Ekstrinsik Terhadap Aktivitas Mengajar Privat Pada Mahasiswa FKIP Universitas Jember Tahun 2013. Skripsi. Program Studi Pendidikan Luar Sekolah Jurusan Ilmu Pendidikan dan Keguruan Universitas Jember.

Moleong, Lexy J. 2005. Metodologi Penelitian Kualitatif. Bandung: PT Remaja. Yogyakarta : P3PKUGM. 
Learning Community: Jurnal Pendidikan Luar Sekolah, 3 (2), September 2019 - 73 Domas Adi Saputro

Nurdiana, G. 2014. Hubungan Kinerja Tutor Dengan Partsipasi Belajar Peserta Didik Progam Kejar Paket C Kelas XXI Di Sanggar Kegiatan Belajar Bondowoso Tahun 2004. Skripsi. Program Studi Pendidikan Luar Sekolah Jurusan Ilmu Tutoran Dan Keguruan Universitas Jember.

Sardiman, A.M. 2011. Interaksi dan Motivasi Belajar Mengajar. Jakarta: PT Raja Grafindo Persada.

Widodo, R.W. 2014. Hubungan Antara Peran Tutor dengan Peningkatan Motivasi Ekstrinsik pada warga belajar kesetaraan paket B di PKBM Bina Sejahtera Kecamatan Sukodono Kabupaten Lumajang. Skripsi. Program Studi Pendidikan Luar Sekolah Jurusan Ilmu Pendidikan dan Keguruan Universitas Jember.

Yunus, H.A. 2016. Telaah aliran Pendidikan progresivisme dan esensialisme dalam perspektif filsafat

Pendidikan. Jurnal Cakrawala

pendas. Vol. 2, No. 1 Januari 2016 